\title{
STUDI PERBANDINGAN PARAMETER KEKUATAN GESER TRIAXIAL (CU) MULTISTAGE DENGAN SINGLESTAGE UNTUK TANAH KLASIFIKASI MH ATAU A-7-5(25)
}

\section{Agus Pronoto, Roesyanto, dan Rudi Iskandar}

Universitas Sumatera Utara, Medan, Indonesia

Email: agus.pronoto@students.usu.ac.id, roesyantos@yahoo.com dan sipil.s2.usu@gmail.com

\begin{tabular}{l}
\hline INFO ARTIKEL \\
\hline Diterima \\
28 Maret 2021 \\
Direvisi \\
4 April 2021 \\
Disetujui \\
5 April 2021 \\
\hline
\end{tabular}

Keywords:

undisturbed, triaxial $C U$, hyperbolic, shear strength

\begin{abstract}
This study aims to compare the results of deviatoric voltage values and pore water pressure and soil shear strength in testing between triaxial CU multistage and singlestage at two different pressures $(\sigma 3)$. The research method used is by singlestage and multistagetesting. This study compares the results of multistage triaxial $C U$ against conventional (singlestage) triaxial test by limiting the axial strain to $4 \%$ during deviatoric phase. The stress value of multistage method are predicted with Kondner hypothesis by using hyperbolic equation for certain strain values $(\infty, 5 \%, 10 \%, 15 \%, 20 \%)$. Soil samples in this study were categorized as $\mathrm{MH}$ for the USCS classification or A-7-5(25) for to the AASHTO classification. It is possible to get result close to the singlestage test by limiting the axial strain to $4 \%$ during deviatoric phase. The stress value predicted by hyperbolic equations by inputing infinite strain tends to produce value greater than the experimental results. Several strain were inputed and evaluated (5\%, 10\%, $15 \%$, and 20\%), it was found using the input of $15 \%$ strain at hyperbolic equation, predicts stress value closer to experimental values. The predicted soil shear strength is quite accurate for $c$ and $\phi$ under total stress conditions and adequate for c' and ' $\phi$ ' under effective stress conditions.
\end{abstract}

\begin{abstract}
ABSTRAK
Penelitian ini bertujuan untuk membandingkan hasil nilai tegangan deviatorik dan tekanan air pori dan kekuatan geser tanah pada pengujian antara triaksial CU multistage dengan singlestage pada dua tekanan pengekang $(\sigma 3)$ yang berbeda. Metode penilitian yang digunakan adalah dengan pengujian singlestage dan multistage. Hal ini
\end{abstract}

\begin{tabular}{ll}
\hline How to cite: & Pronoto, Agus et al., (2021) Studi Perbandingan Parameter Kekuatan Geser Triaxial (Cu) Multistage \\
& Dengan Singlestage Untuk Tanah Klasifikasi Mh Atau A-7-5(25). Jurnal Syntax Admiration 2(4). \\
& https://doi.org/10.46799/jsa.v2i4.210 \\
& $2723-6927$ \\
E-ISSN: & Ridwan Institute \\
Published by: &
\end{tabular}




\begin{tabular}{|c|c|}
\hline $\begin{array}{l}\text { Kata Kunci: } \\
\text { undisturbed, triaksial CU, } \\
\text { hiperbolik, kekuatan geser } \\
\text { tanah }\end{array}$ & $\begin{array}{l}\text { sering menyebabkan beberapa pengujian sampel di } \\
\text { laboratorium ditiadakan akibat keterbatasan jumlah } \\
\text { sampel, salah satunya adalah pengujian triaksial. } \\
\text { Penelitian ini membandingkan hasil pengujian triaksial } \\
\text { CU multistage dengan batasan regangan aksial } 4 \% \text { pada } \\
\text { fase deviatorik terhadap pengujian triaksial CU } \\
\text { konvensional (singlestage). Hasil pengujian metode } \\
\text { multistage kemudian diprediksi nilai tegangannya dengan } \\
\text { menggunakan persamaan hiperbolik hipotesa Kondner } \\
\text { untuk beberapa nilai regangan tertentu ( } \infty \text {, 5\%, 10\%, } \\
\text { 15\%, 20\%). Sampel tanah penelitian dikategorikan } \\
\text { sebagai MH menurut klasifikasi USCS atau A-7-5(25) } \\
\text { menurut klasifikasi AASHTO. Pembatasan regangan } \\
\text { aksial 4\% pada fase deviatorik memungkinkan hasil akhir } \\
\text { yang mendekati pengujian singlestage. Prediksi nilai } \\
\text { tegangan menggunakan persamaan hiperbolik dengan } \\
\text { input regangan tidak terhingga ( } \infty \text { ) cenderung } \\
\text { menghasilkan nilai yang lebih besar dari hasil } \\
\text { eksperimental. Dari beberapa input nilai regangan yang } \\
\text { dievaluasi yaitu 5\%, 10\%, 15\%, dan 20\%, diperoleh } \\
\text { prediksi nilai dengan input regangan 15\% pada } \\
\text { persamaan hiperbola menghasilkan prediksi nilai lebih } \\
\text { mendekati hasil eksperimental. Nilai parameter kekuatan } \\
\text { geser tanah diperoleh hasil cukup akurat untuk c dan } \phi \\
\text { pada kondisi tegangan total dan diperoleh memadai untuk } \\
\text { c' dan } \phi \text { pada kondisi tegangan efektif. }\end{array}$ \\
\hline
\end{tabular}

\section{Pendahuluan}

Pada kondisi tanah lunak pengambilan sampel tanah tidak terganggu tidak jarang mengalami kesulitan dan cenderung memperoleh sampel dengan recovery rate yang rendah. Pada kondisi tersebut kadang-kadang beberapa pengujian yang membutuhkan beberapa spesimen dalam satu jenis pengujian kerap kali dibatalkan akibat keterbatasan jumlah spesimen pengujian, salah satunya adalah pengujian triaksial (Sharma et al., 2014).

Pada umumnya pengujian triaksial membutuhkan sampel sebanyak tiga spesimen untuk dilaksanakan pengujiannya masing-masing di bawah kondisi tekanan pengekang ( $\sigma 3)$ yang berbeda (Effio et al., 2015). Metode multistage dapat menjawab permasalahan tersebut di mana jumlah spesimen yang diperlukan hanya satu, namun tetap mengikuti tahapan pengujian yang sama seperti pengujian triaksial pada umumnya (konvensional/singlestage) (Yawei et al., 2020).

Metode multistage ini pertama kali diperkenalkan oleh (Banerjee et al., 2018) sebagai metode alternatif pengujian triaksial konvensional. (Khosravi et al., 2012) melaporkan hasil penelitiannya bahwa nilai kohesi (c') dan sudut geser dalam ( $\phi$ ') pada kondisi tegangan efektif menghasilkan nilai yang logis dan dapat diterima pada pengujian triaksial CU multistage. Pada penelitiannya spesimen uji dikonsolidasi di 
bawah tekanan pengekang tertentu kemudian dibebani hingga hampir mencapai regangan keruntuhan, spesimen uji kemudian dikonsolidasi kembali dengan tekanan pengekang $(\sigma 3)$ yang lebih besar dan dibebani hingga hampir mencapai keruntuhan (Minaeian et al., 2020). Prosedur tersebut mungkin memberikan hasil yang logis untuk beberapa jenis tanah, dan regangan aksial yang terjadi pada kondisi tahap terakhir menghasilkan regangan aksial yang sangat besar hanya pada satu spesimen (Yang et al., 2019).

Untuk mengatasi permasalahan tersebut, (Ravi Sharma et al., 2011) dalam penelitiannya menyebutkan bahwa hubungan tegangan regangan hiperbolik dapat digunakan untuk memprediksi nilai tegangan deviatorik dan tekanan air pori pada kondisi keruntuhan walaupun dengan pengujian pada kondisi regangan aksial rendah (2\% hingga 4\%) dengan menggunakan hipotesa (Alyousif, 2015). Tegangan deviatorik dan tekanan air pori dapat diprediksi menggunakan persamaan (1) dan (2).

$$
\begin{aligned}
& \frac{\varepsilon}{\left(\sigma_{1}-\sigma_{3}\right)}=a+b \cdot \varepsilon \\
& \frac{\varepsilon}{(\Delta u)}=a_{u}+b_{u} \cdot \varepsilon
\end{aligned}
$$

di mana:

$$
\begin{aligned}
\sigma 1-\sigma 3= & \text { tegangan deviatorik } \\
\varepsilon & =\text { regangan aksial } \\
\mathrm{a} & =\text { perpotongan-y hubungan } \varepsilon /(\sigma 1-\sigma 3) \\
& \text { terhadap } \varepsilon \\
\mathrm{b} \quad= & \text { slope hubungan } \varepsilon /(\sigma 1-\sigma 3) \text { terhadap } \varepsilon \\
\Delta \mathrm{u} \quad= & \text { perubahan tekanan air pori } \\
\mathrm{au} \quad= & \text { perpotongan-y hubungan } \varepsilon /(\mathrm{u}) \\
& \text { terhadap } \varepsilon \\
\mathrm{bu} \quad= & \text { slope hubungan } \varepsilon /(\mathrm{u}) \text { terhadap } \varepsilon
\end{aligned}
$$

dengan memplotkan hubungan $\varepsilon /(\sigma 1-\sigma 3)$ terhadap $\varepsilon$ dan hubungan $\varepsilon /(\Delta \mathrm{u})$ terhadap $\varepsilon$ maka sama-sama akan membentuk suatu garis linear di mana a merupakan perpotongan terhadap sumbu-y dan b merupakan kemiringan/slope garis linear (Dexing et al., 2018).

Prediksi nilai menggunakan hipotesa Kondner (1) dan (2) dengan nilai regangan tidak terhingga (asimtotik) umumnya cenderung menghasilkan prediksi nilai yang lebih tinggi (Khosravi et al., 2012). (Ravi Sharma et al., 2011) dalam penelitiannya menyarankan bahwa prediksi nilai tegangan menggunakan hipotesa Kondner pada Persamaan (1) dan (2) akan menghasilkan prediksi nilai yang lebih baik apabila diekstrapolasi ke nilai regangan tertentu yaitu nilai regangan $15 \%$.

Penelitian ini bertujuan untuk membandingkan hasil nilai tegangan deviatorik dan tekanan air pori dan kekuatan geser tanah pada pengujian antara triaksial CU multistage dengan singlestage pada dua tekanan pengekang $(\sigma 3)$ yang berbeda. 


\section{Metode Penelitian}

Sampel tanah tidak terganggu berasal dari daerah Terjun-marelan dan diambil pada kedalaman 11,00 m hingga $11,65 \mathrm{~m}$. Karakteristik dan indeks properti tanah dapat dilihat pada Tabel 1 (Hou et al., 2017).

\section{Tabel 1}

Karakteristik dan Indeks Properti Tanah

\begin{tabular}{cc}
\hline Keterangan & Tanah Terjun-Marelan \\
\hline Berat isi tanah, $\gamma_{\mathrm{t}}$ & $1,50 \mathrm{~g} / \mathrm{cm}^{3}$ \\
\hline Berat kering tanah, $\gamma_{\mathrm{d}}$ & $0,79 \mathrm{~g} / \mathrm{cm}^{3}$ \\
\hline Specific Gravity, $\mathrm{G}_{\mathrm{s}}$ & 2,46 \\
\hline Batas cair, $L L$ & $52,41 \%$ \\
\hline Indeks Plastisitas, $P I$ & $21,85 \%$ \\
\hline Klasifikasi USCS & $\mathrm{MH}$ \\
\hline Klasifikasi AASHTO & $\mathrm{A}-7-5(25)$ \\
\hline
\end{tabular}

Sampel uji triaksial dipersiapkan sebanyak 2 spesimen untuk singlestage dan 1 spesimen untuk multistage dengan masing-masing ukuran diameter $38 \mathrm{~mm}$ dan tinggi $76 \mathrm{~mm}$.

Pada pengujian triaksial CU singlestage, masing-masing spesimen akan melewati tiga fase, yaitu fase saturasi, fase kompresi dan fase deviatorik. Pada fase saturasi, spesimen dianggap jenuh apabila mencapai tingkat saturasi $\geq 95 \%$. Kemudian pada fase kompresi, spesimen 1 diberi tekanan pengekang sebesar $0,7 \mathrm{~kg} / \mathrm{cm} 2$ dan dibiarkan terkonsolidasi selama 24 jam dan pada spesimen 2 diberi tekanan pengekang sebesar 2.8 $\mathrm{kg} / \mathrm{cm} 2$ dan dibiarkan terkonsolidasi selama $24 \mathrm{jam}$. Pada fase deviatorik spesimen dibebani dengan kecepatan pembebanan $0,014 \mathrm{~mm} / \mathrm{menit}$ hingga mencapai regangan aksial 20\%. Bagan alir pengujian triaksial CU singlestage dapat dilihat pada Gambar 1.

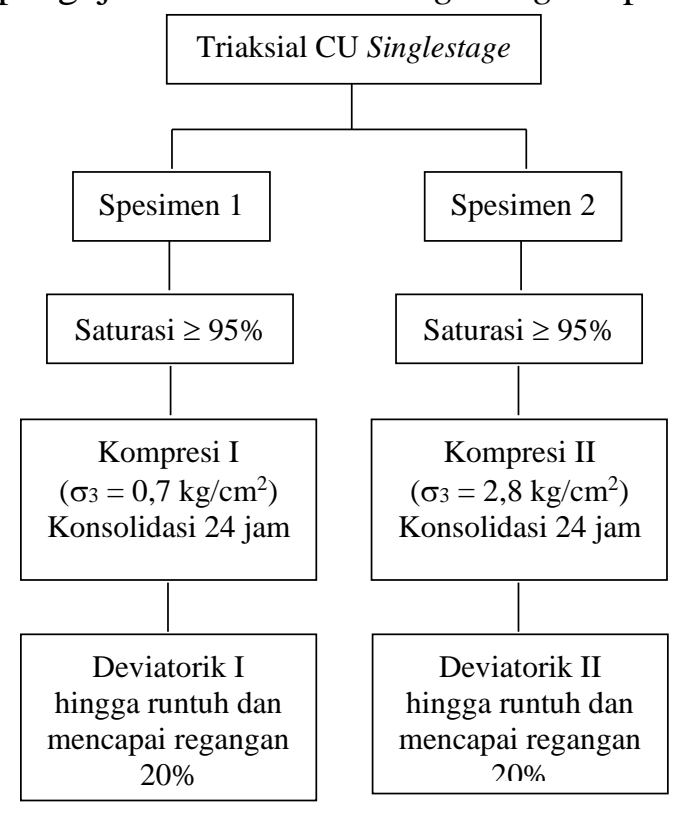

Gambar 1

Bagan Alir Pengujian Singlestage 
Pada pengujian triaksial CU multistage, spesimen akan melalui proses pengujian yang sama dengan pengujian singlestage, yang berbeda adalah pada pengujian multistage hanya menggunakan 1 spesimen pada fase saturasi hingga $\geq 95 \%$. Spesimen kemudian dilanjutkan ke fase kompresi dengan pemberian tekanan pengekang 0,7 $\mathrm{kg} / \mathrm{cm} 2$ dan dibiarkan terkonsolidasi selama 24 jam. Pada fase deviatorik, spesimen dibebani namun tidak hingga mengalami keruntuhan, melainkan regangannya dibatasi hanya mencapai $4 \%$. Spesimen kemudian diberikan tekanan pengekang tambahan hingga $2,8 \mathrm{~kg} / \mathrm{cm} 2$ dan dibiarkan terkonsolidasi selama 24 jam berikutnya. Kemudian dilanjutkan ke fase deviatorik selanjutnya hingga mencapai regangan aksial 20\% (Prakash et al., 2018). Bagan alir pengujian triaksial CU multistage dapat dilihat pada Gambar 2.

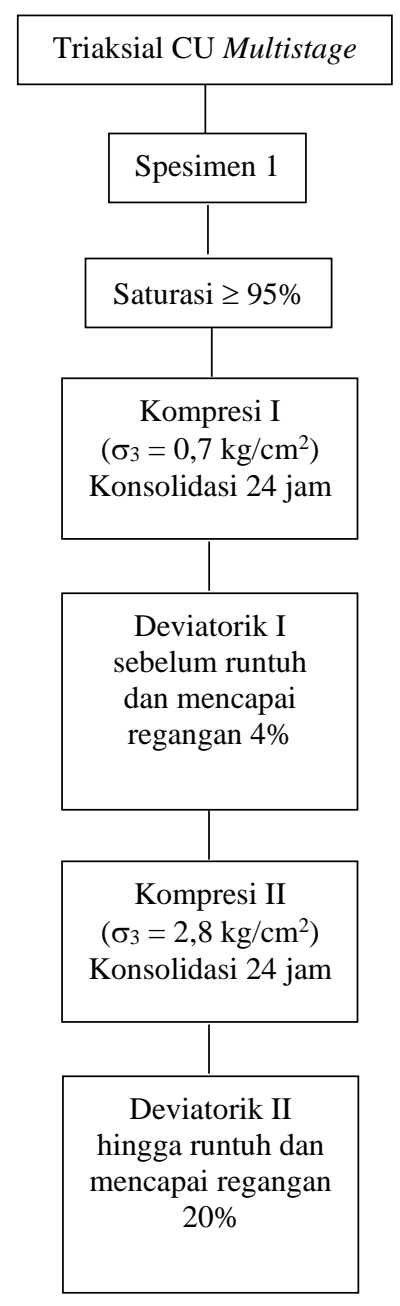

\section{Gambar 2}

Bagan Alir Pengujian Multistage

\section{Hasil dan Pembahasan}

A. Tegangan deviatorik dan tekanan air pori

Hasil pengujian triaksial CU singlestage pada kondisi keruntuhan dapat dilihat pada Tabel 2 dan Gambar 3. 
Tabel 2

Rangkuman Nilai Pengujian Singlestage

\begin{tabular}{ccc}
\hline $\begin{array}{c}\text { Tekanan } \\
\text { pengekang, } \sigma_{3}\end{array}$ & $\left(\sigma_{1}-\sigma_{3}\right)_{\mathbf{f}}$ & $\Delta \mathbf{u}_{\mathbf{f}}$ \\
\hline $0,7 \mathrm{~kg} / \mathrm{cm}^{2}$ & $0,870 \mathrm{~kg} / \mathrm{cm}^{2}$ & $0,48 \mathrm{~kg} / \mathrm{cm}^{2}$ \\
$2,8 \mathrm{~kg} / \mathrm{cm}^{2}$ & $2,723 \mathrm{~kg} / \mathrm{cm}^{2}$ & $1,63 \mathrm{~kg} / \mathrm{cm}^{2}$ \\
\hline
\end{tabular}

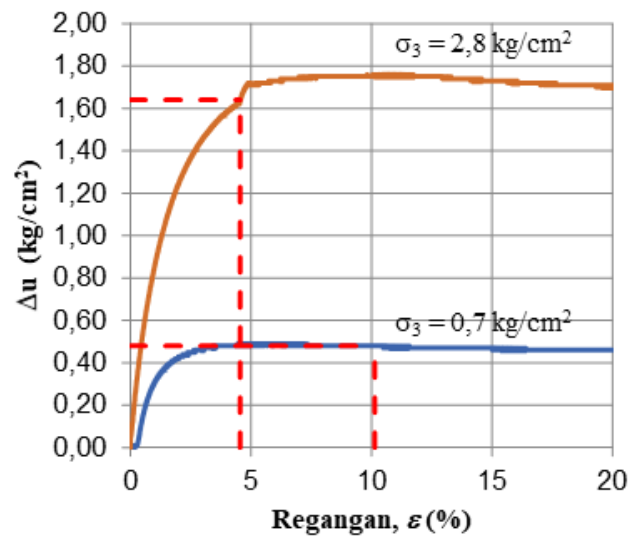

Gambar 3

Tegangan-Regangan Uji Singlestage

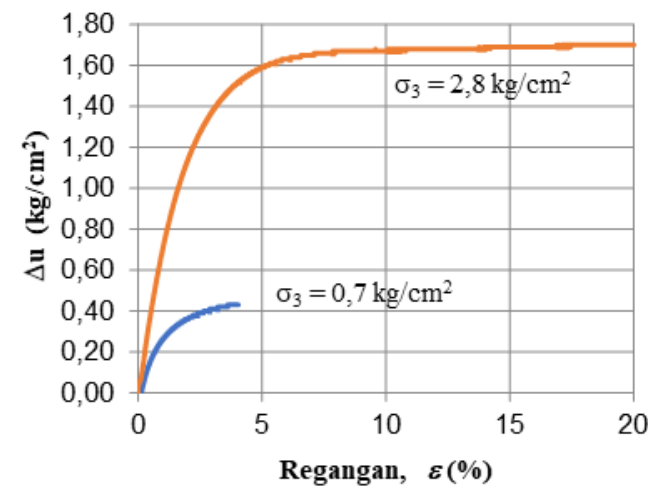

\section{Gambar 4}

Tegangan-Regangan Uji Multistage

Hasil pengujian triaksial CU multistage pada Gambar 4 tidak dapat lansung ditentukan nilai keruntuhannya dan harus diolah terlebih dahulu dengan memplot hubungan $\varepsilon /(\sigma 1-\sigma 3)$ terhadap $\varepsilon$ yang dapat dilihat pada Gambar 5 dan hubungan $\varepsilon / \Delta \mathrm{u}$ terhadap $\varepsilon$ yang dapat dilihat pada Gambar 6 .

Nilai a dan b serta au dan bu didapat dari persamaan regresi linear, untuk kondisi tekanan pengekang $0,7 \mathrm{~kg} / \mathrm{cm} 2$ dapat dilihat pada Gambar 5 dan untuk kondisi tekanan pengekang 2,8 kg/cm2 dapat dilihat pada Gambar 6 (Wild et al., 2017). Prediksi nilai tegangan deviatorik dan perubahan tekanan air pori pada kondisi keruntuhan dapat dihitung menggunakan hipotesa Kondner pada Persamaan 
(1) dan Persamaan (2) dengan input beberapa nilai regangan yaitu regangan $\infty, 5 \%$, $10 \%, 15 \%$, dan 20\% (Nam et al., 2011). Hasil prediksi nilai dapat dilihat pada Tabel 3 dan Tabel 4.

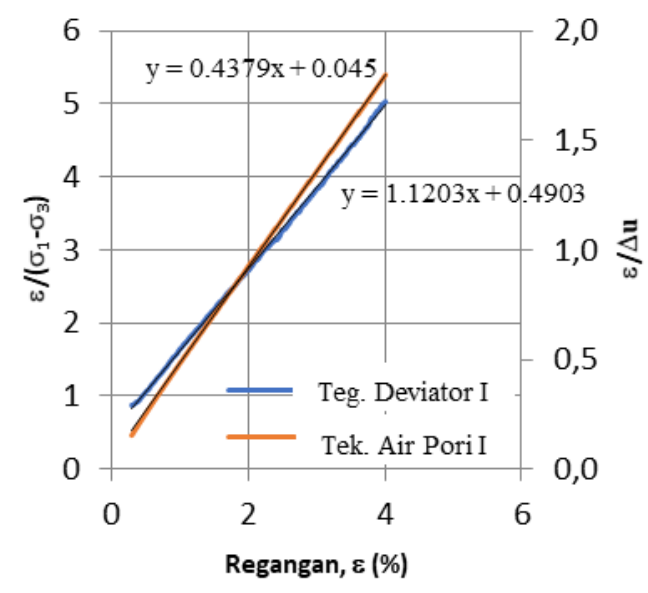

Gambar 5

Grafik Regresi Linear Hubungan $\varepsilon /(\sigma 1-\sigma 3)$ Terhadap $\varepsilon$ Tahap I, $\sigma 3=0,7 \mathrm{Kg} / \mathrm{Cm} 2$ (Multistage)

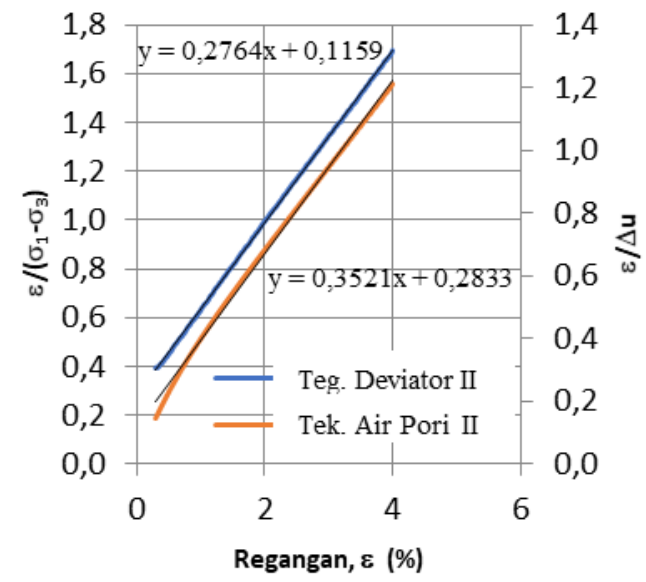

Gambar 6

Grafik Regresi Linear Hubungan $\varepsilon /(\mathrm{U})$ Terhadap $\varepsilon$ Tahap I, $\sigma 3=0,7$ Kg/Cm2 (Multistage) 


\section{Tabel 3}

Perbandingan Hasil Eksperimental Singlestage dengan Prediksi Nilai $(\sigma 1-\sigma 3)$

\section{Multistage}

\begin{tabular}{|c|c|c|c|c|c|c|c|c|c|c|c|}
\hline \multirow{2}{*}{$\begin{array}{l}\text { Singlestage } \\
\sigma 3 \mathrm{~kg} / \mathrm{cm}^{2}\end{array}$} & \multicolumn{3}{|c|}{ Asimtotik } & \multicolumn{8}{|c|}{ Prediksi nilai $(\sigma 1-\sigma 3)$ menggunakan persamaan (1) untuk regangan aksial } \\
\hline & $\begin{array}{c}(\sigma 1- \\
\sigma 3) \mathrm{f} \\
\mathrm{kg} / \mathrm{cm}\end{array}$ & $\begin{array}{c}(\sigma 1- \\
\sigma 3)=1 / \mathrm{b} \\
\mathrm{kg} / \mathrm{cm}^{2}\end{array}$ & $\begin{array}{c}\text { Kesesuaian } \\
\%\end{array}$ & $\varepsilon=5 \%$ & $\begin{array}{c}\text { Kesesuaian } \\
\%\end{array}$ & $\varepsilon=10 \%$ & $\begin{array}{c}\text { Kesesuaian } \\
\%\end{array}$ & $\varepsilon=15 \%$ & $\begin{array}{c}\text { Kesesuaian } \\
\%\end{array}$ & $\varepsilon=20 \%$ & $\begin{array}{c}\text { Kesesuaian } \\
\%\end{array}$ \\
\hline 0,7 & 0,870 & 0,893 & 102,60 & 0,821 & 94,34 & 0,855 & 98,30 & 0,867 & 99,69 & 0,874 & 100,40 \\
\hline 2,8 & 2,723 & 2,480 & 104,30 & 2,446 & 89,84 & 2,629 & 96,53 & 2,696 & 98,99 & 2,730 & 100,27 \\
\hline \multicolumn{12}{|c|}{ Persentase kesesuaian rata-rata } \\
\hline & & & 103,45 & & 92,09 & & 97,42 & & 99,34 & & 100,33 \\
\hline
\end{tabular}

\section{Tabel 4}

Perbandingan Hasil Eksperimental Singelstage dengan Prediksi Nilai $(\Delta \mathbf{U})$ Multistage

\begin{tabular}{|c|c|c|c|c|c|c|c|c|c|c|c|}
\hline \multirow{2}{*}{$\begin{array}{c}\text { Singlestage } \\
\sigma 3 \mathrm{~kg} / \mathrm{cm}^{2}\end{array}$} & \multicolumn{3}{|c|}{ Asimtotik } & \multicolumn{8}{|c|}{ Prediksi nilai $(\sigma 1-\sigma 3)$ menggunakan persamaan (1) untuk regangan aksial } \\
\hline & $\begin{array}{c}(\sigma 1- \\
\sigma 3) f \\
\mathrm{~kg} / \mathrm{cm}\end{array}$ & $\begin{array}{c}(\sigma 1- \\
\sigma 3)=1 / \mathbf{b} \\
\mathrm{kg} / \mathrm{cm}^{2}\end{array}$ & $\begin{array}{c}\text { Kesesuaian } \\
\%\end{array}$ & $\varepsilon=5 \%$ & $\begin{array}{c}\text { Kesesuaian } \\
\%\end{array}$ & $\varepsilon=10 \%$ & $\begin{array}{c}\text { Kesesuaian } \\
\%\end{array}$ & $\varepsilon=15 \%$ & $\begin{array}{c}\text { Kesesuaian } \\
\%\end{array}$ & $\varepsilon=20 \%$ & $\begin{array}{c}\text { Kesesuaian } \\
\%\end{array}$ \\
\hline 0,7 & 0,480 & 0,484 & 100,76 & 0,438 & 91,17 & 0,460 & 95,92 & 0,468 & 97,52 & 0,472 & 98,32 \\
\hline 2,8 & 1,640 & 1,818 & 110,85 & 1,538 & 93,78 & 1,672 & 101,97 & 1,720 & 104,85 & 1,744 & 106,32 \\
\hline \multicolumn{12}{|c|}{ Persentase kesesuaian rata-rata } \\
\hline & & & 105,80 & & 92,48 & & 98,94 & & 101,18 & & 102,32 \\
\hline
\end{tabular}

B. Kekuatan Geser Tanah

Keruntuhan Mohr-Coulomb pada pengujian singlestage dapat dilihat pada Gambar 7 (Xu et al., 2018). Untuk pengujian multistage diperoleh hasil yang mendekati hasil singlestage berada pada regangan 15\%. Keruntuhan Mohr-Coulomb berdasarkan prediksi nilai pada regangan $15 \%$ dapat dilihat pada Gambar 8 (Alyousif, 2015). Perbandingan parameter kekuatan geser tanah pada kondisi tegangan total dan efektif dapat dilihat pada Tabel 5.

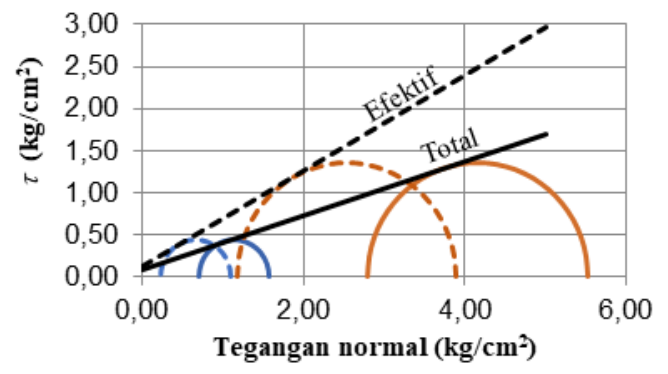

\section{Gambar 7}

Keruntuhan Mohr-Coulomb Triaksial CU Singlestage 


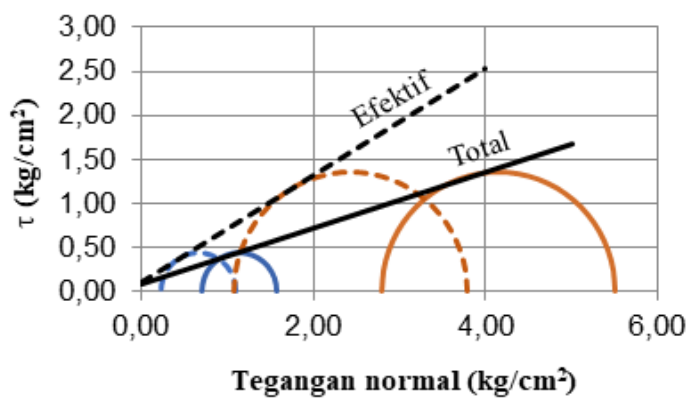

Gambar 8

Keruntuhan Mohr-Coulomb Triaksial CU Multistage

Tabel 5

Perbandingan Parameter Kekuatan Geser Tanah Triaksial CU (Singlestage Vs Multistage)

\begin{tabular}{cccc}
\hline $\begin{array}{c}\text { Tegangan } \\
\text { total }\end{array}$ & Singlestage & Multistage & $\begin{array}{c}\text { Persentase } \\
\text { kesesuaian }\end{array}$ \\
\hline $\mathbf{c}\left(\mathrm{kg} / \mathrm{cm}^{2}\right)$ & 0,092 & 0,094 & $102,17 \%$ \\
\hline$\phi\left(^{\circ}\right)$ & 17,83 & 17,65 & $98,99 \%$ \\
\hline $\begin{array}{c}\text { Tegangan } \\
\text { efektif }\end{array}$ & Singlestage & Multistage & $\begin{array}{c}\text { Persentase } \\
\text { kesesuaian }\end{array}$ \\
\hline $\mathrm{c}^{\prime}\left(\mathrm{kg} / \mathrm{cm}^{2}\right)$ & 0,125 & 0,103 & $82,40 \%$ \\
\hline$\phi^{\prime}\left({ }^{\circ}\right)$ & 29,68 & 31,24 & $105,26 \%$ \\
\hline
\end{tabular}

\section{Kesimpulan}

Penggunaan input regangan $(\infty)$ menggunakan persamaan hiperbolik Kondner dengan cenderung menghasilkan prediksi nilai tegangan yang lebih besar dari hasil eksperimental. Pada input regangan (5\%, 10\%, 15\% dan 20\%) yang dievaluasi, diperoleh pada regangan $15 \%$ prediksi nilai tegangan yang dihasilkan lebih mendekati nilai hasil eksperimental dengan kesesuaian rata-rata 99,34\% untuk prediksi nilai ( $\sigma 1-$ $\sigma 3)$ dan $101,18 \%$ untuk prediksi nilai $(\Delta \mathrm{u})$. Untuk kekuatan geser tanah yang dihasilkan menggunakan metode ini diperoleh hasil yang cukup akurat pada kondisi tegangan total dengan kesesuaian rata-rata $102,17 \%$ untuk c dan 98,99\% untuk $\phi$. Namun untuk kondisi tegangan efektif, kekuatan geser yang diperoleh memadai dengan kesesuaian rata-rata $82,40 \%$ untuk nilai c' dan $105,26 \%$ untuk nilai $\phi '$. Dari hasil perbandingan prediksi nilai dan kekuatan geser tanah tersebut disimpulkan bahwa pembatasan regangan aksial $4 \%$ pada pengujian triaksial CU multistage dan prediksi nilai pada regangan $15 \%$ memungkinkan untuk mendapatkan hasil yang mendekati hasil eksperimental. 


\section{BIBLIOGRAFI}

Alyousif, M. (2015). Development Of Computer-Controlled Triaxial Test Setup And Study On Multistage Triaxial Test On Sand. Google Scholar

Banerjee, A., Puppala, A. J., Patil, U. D., Hoyos, L. R., \& Bhaskar, P. (2018). A Simplified Approach To Determine The Response Of Unsaturated Soils Using Multistage Triaxial Test. In IFCEE 2018 (Pp. 332-342). Google Scholar

Dexing, L., Enyuan, W., Xiangguo, K., Xiaoran, W., Chong, Z., Haishan, J., Hao, W., \& Jifa, Q. (2018). Fractal Characteristics Of Acoustic Emissions From Coal Under Multi-Stage True-Triaxial Compression. Journal Of Geophysics And Engineering, 15(5), 2021-2032. Google Scholar

Effio, C. L., Wenger, L., Ötes, O., Oelmeier, S. A., Kneusel, R., \& Hubbuch, J. (2015). Downstream Processing Of Virus-Like Particles: Single-Stage And Multi-Stage Aqueous Two-Phase Extraction. Journal Of Chromatography A, 1383, 35-46. Google Scholar

Hou, B., Chen, M., Wan, C., \& Sun, T. (2017). Laboratory Studies Of Fracture Geometry In Multistage Hydraulic Fracturing Under Triaxial Stresses. Chemistry And Technology Of Fuels And Oils, 53(2), 219-226. Google Scholar

Khosravi, A., Alsherif, N., Lynch, C., \& Mccartney, J. (2012). Multistage Triaxial Testing To Estimate Effective Stress Relationships For Unsaturated Compacted Soils. Geotechnical Testing Journal, 35(1), 128-134. Google Scholar

Minaeian, V., Dewhurst, D. N., \& Rasouli, V. (2020). An Investigation On Failure Behaviour Of A Porous Sandstone Using Single-Stage And Multi-Stage True Triaxial Stress Tests. Rock Mechanics And Rock Engineering, 53(8), 3543-3562. Google Scholar

Nam, S., Gutierrez, M., Diplas, P., \& Petrie, J. (2011). Determination Of The Shear Strength Of Unsaturated Soils Using The Multistage Direct Shear Test. Engineering Geology, 122(3-4), 272-280. Goggle Scholar

Prakash, S., Myers, M. T., \& Hathon, L. A. (2018). Analysis Of Damage Induced During A Multi-Stage Triaxial Test Using Acoustic Emissions. 52nd US Rock Mechanics/Geomechanics Symposium. Google Scholar

Ravi Sharma, M. S., Baxter, C. D. P., Moran, K., Vaziri, H., \& Narayanasamy, R. (2011). Strength Of Weakly Cemented Sands From Drained Multistage Triaxial Tests. Journal Of Geotechnical And Geoenvironmental Engineering, 137(12), 1202-1210. Google Scholar

Sharma, S., Dwivedi, V. K., \& Pandit, S. N. (2014). Exergy Analysis Of Single - Stage And Multi Stage Thermoelectric Cooler. International Journal Of Energy 
Research, 38(2), 213-222. Google Scholar

Wild, K. M., Barla, M., Turinetti, G., \& Amann, F. (2017). A Multi-Stage Triaxial Testing Procedure For Low Permeable Geomaterials Applied To Opalinus Clay. Journal Of Rock Mechanics And Geotechnical Engineering, 9(3), 519-530. Google Scholar

Xu, Y., Wu, S., Williams, D. J., \& Serati, M. (2018). Determination Of Peak And Ultimate Shear Strength Parameters Of Compacted Clay. Engineering Geology, 243, 160-167. Google Scholar

Yang, S.-Q., Tian, W.-L., Jing, H.-W., Huang, Y.-H., Yang, X.-X., \& Meng, B. (2019). Deformation And Damage Failure Behavior Of Mudstone Specimens Under Single-Stage And Multi-Stage Triaxial Compression. Rock Mechanics And Rock Engineering, 52(3), 673-689. Google Scholar

Yawei, L., Ziyuan, W., \& Ahmad, G. (2020). Single Stage And Multistage Confined Brazilian Test. 54th US Rock Mechanics/Geomechanics Symposium. Google Scholar

\section{Copyright holder:}

Agus Pronoto, Roesyanto, dan Rudi Iskandar (2021)

First publication right:

Journal Syntax Admiration

This article is licensed under:

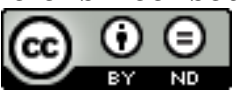

